\title{
UC Davis
}

Recent Work

\section{Title}

Lifecycle impacts of natural gas to hydrogen pathways on urban air quality

\section{Permalink}

https://escholarship.org/uc/item/4fs2b9bv

\section{Authors}

Wang, Guihua

Ogden, Joan M

Nicholas, Michael A

\section{Publication Date}

2007-12-01

Peer reviewed 


\title{
Lifecycle impacts of natural gas to hydrogen pathways on urban air quality
}

\author{
Guihua Wang ${ }^{\mathrm{a}, *}$, Joan M. Ogden ${ }^{\mathrm{b}}$, Michael A. Nicholas ${ }^{\mathrm{c}}$ \\ ${ }^{a}$ Department of Civil and Environmental Engineering and Institute of Transportations Studies, University of California, Davis, CA 95616, USA \\ ${ }^{\mathrm{b}}$ Department of Environmental Science and Policy and Institute of Transportations Studies, University of California, Davis, CA 95616, USA \\ ${ }^{\mathrm{c}}$ Institute of Transportations Studies, University of California, Davis, CA 95616, USA
}

Received 21 October 2006; received in revised form 10 January 2007; accepted 10 January 2007

Available online 27 February 2007

\begin{abstract}
In this paper we examine the potential air quality impacts of hydrogen transportation fuel from a lifecycle analysis perspective, including impacts from fuel production, delivery, and vehicle use. We assume that hydrogen fuel cell vehicles are introduced in a specific region, Sacramento County, California. We consider two levels of market penetration where $9 \%$ or $20 \%$ of the light duty fleet are hydrogen fuel cell vehicles. The following three natural gas to hydrogen supply pathways are assessed in detail and compared in terms of emissions and the resulting changes in ambient air quality: (1) onsite hydrogen production; (2) centralized hydrogen production with gaseous hydrogen pipeline delivery systems; and (3) centralized hydrogen production with liquid hydrogen truck delivery systems. All the pathways examined use steam methane reforming (SMR) of natural gas to produce hydrogen. The source contributions to incremental air pollution are estimated and compared among hydrogen pathways. All of the hydrogen pathways result in extremely low contributions to ambient air concentrations of $\mathrm{NO}_{x}$, $\mathrm{CO}_{\text {, }}$ particulates, and $\mathrm{SO}_{x}$, typically less than $0.1 \%$ of the current ambient pollution for both levels of market penetration. Among the hydrogen supply options, it is found that the central SMR with pipeline delivery systems is the lowest pollution option available provided the plant is located to avoid transport of pollutants into the city via prevailing winds. The onsite hydrogen pathway is comparable to the central hydrogen pathway with pipeline systems in terms of the resulting air pollution. The pathway with liquid hydrogen trucks has a greater impact on air quality relative to the other pathways due to emissions associated with diesel trucks and electricity consumption to liquefy hydrogen. However, all three hydrogen pathways result in negligible air pollution in the region.
\end{abstract}

(C) 2007 International Association for Hydrogen Energy. Published by Elsevier Ltd. All rights reserved.

Keywords: Lifecycle analysis (LCA); Transportation; Fuel cell vehicles (FCV); Hydrogen; Natural gas (NG); Hydrogen pathways; SMR; Air pollution; Source contributions

\section{Introduction}

There is growing interest in hydrogen as a transportation fuel. One of the key motivations for hydrogen is its potential to reduce emissions of air pollutants. Although hydrogen fuel cell vehicles (HFCVs) emit no tailpipe emissions, hydrogen must be produced from other sources and delivered to users. These steps can generate air pollutant emissions. Thus, the entire lifecycle from well to wheels (WTW) must be considered in an assessment of hydrogen's air quality impacts.

\footnotetext{
* Corresponding author. Fax: +15307526572.

E-mail address: wghwang@ucdavis.edu (G. Wang).
}

Clearly, emissions for hydrogen (and associated environmental impacts) will depend on how hydrogen is made. Further, air quality is related to emissions in complex ways that depend on the mix of emissions sources, meteorology, and geography.

In this study we estimate regional air quality impacts for three different hydrogen production and delivery pathways, based on steam methane reforming (SMR) of natural gas, which is currently the most common way of making hydrogen. From a lifecycle analysis (LCA) perspective, this research compares these pathways, presents the methodology to link hydrogen pathways to ambient air quality in urban Sacramento, California, and estimates the increases in ambient pollution corresponding to some key hydrogen supply chain steps. 


\section{Methodology}

\subsection{Estimating hydrogen demand}

We consider two scenarios, where $9 \%$ and $20 \%$ of light duty vehicles in Sacramento are HFCVs. We keep the number of gasoline vehicles constant in both scenarios, and add hydrogen vehicles and supply systems to the Sacramento area. Thus, the total vehicle population is the sum of the year 2000 light duty gasoline fleet plus the added hydrogen vehicles. This allows us to estimate the incremental impact of hydrogen energy systems on ambient pollution levels in the Sacramento area, without the complexities of simultaneously reducing the number of gasoline vehicles (see Section 3.1). Table 1 shows demographic data for Sacramento [1]. From these and hydrogen vehicle assumptions we estimate regional hydrogen demand for vehicle use for each scenario (see Table 2).

\subsection{Supply options considered}

For each market penetration, the following three natural gas to hydrogen pathways are considered [2]:

- onsite hydrogen production (i.e., the onsite pathway, see Fig. 1);

- centralized hydrogen production with gaseous hydrogen pipeline delivery systems (i.e., the pipeline pathway, see Fig. 2); and

- centralized hydrogen production with liquid hydrogen truck delivery systems (i.e., the truck pathway, see Fig. 3).

The technologies making up the hydrogen energy supply are assumed to have efficiencies and emissions corresponding to current (year 2005) technologies (see Table 3) [3].

Table 1

Demographic data for Sacramento

\begin{tabular}{ll}
\hline Parameters & Value \\
\hline City population in Sacramento (in 2000) & 1.393 million \\
Vehicle ownership & 0.8 vehicles/person \\
Vehicle miles traveled per year (VMT) & 15,000 miles/year \\
\hline
\end{tabular}

Table 2

Hydrogen vehicle assumptions and hydrogen demand

\begin{tabular}{lll}
\hline Parameters & Scenario 1 & Scenario 2 \\
\hline HFCV fleet fraction & $9 \%$ & $20 \%$ \\
Number of HFCVs & 111,400 & 278,600 \\
Hydrogen fuel demand & $78,000 \mathrm{~kg} /$ day & $195,000 \mathrm{~kg} / \mathrm{day}$ \\
Number of hydrogen stations & 27 & 66 \\
Fuel economy of HFCV & $60 \mathrm{miles} / \mathrm{kg}$ of hydrogen & \\
Hydrogen consumption & $0.7 \mathrm{~kg} / \mathrm{vehicle} /$ day & \\
Hydrogen station size & $3000 \mathrm{~kg} /$ day & \\
Liquid truck capacity & $3000 \mathrm{~kg}$ of liquid hydrogen &
\end{tabular}

\subsection{Lifecycle emission inventories of hydrogen pathways}

To estimate the environmental impacts of hydrogen vehicles we consider all emissions associated with the system. The full fuel cycle for a given transportation fuel, also called WTW, includes the following processes: feedstock extraction, feedstock transport; fuel production, storage, distribution, dispensing, and vehicle operation [4]. Not only direct emissions rising from a primary fuel pathway but also indirect emissions associated with sub-pathways are taken into consideration. Fig. 4 presents the concept of an integrated natural gas to hydrogen pathway with liquid hydrogen truck delivery systems, and the dashed line area delimits the parts of lifecycle system that are included in this analysis [2].

In this case study we have chosen to neglect the impact of spatially distant pathway steps (such as natural gas extraction and oil refining) on air quality in Sacramento. However, we do consider emissions from the electricity used in hydrogen pathways steps. Electricity consumed in both primary hydrogen pathway and sub-pathways is assumed to come from the average power mix for Sacramento. The electric generation mix in Sacramento is derived from US Department of Energy's eGRID2002 data for the year 2000 [5]. The power control area (PCA) of interest is defined as the Sacramento municipal utility district only. There are 17 power plants serving the region and their profiles are shown in Table 4. The electric generation mix (i.e., percentage of each $\mathrm{kWh}$ of electricity generated in 2000) by fuel type is summarized in Table 5. Electricity from clean renewables (i.e., solar, wind, and hydro) in Sacramento accounts for more than $42 \%$ of electric generation mix, which makes it not as severely polluting as in other regions to consume a large amount of electricity to compress or liquefy hydrogen.

Heavy-duty diesel-fueled trucks delivering liquid hydrogen are considered as a mobile source of emissions. Liquid hydrogen trucks are assumed to travel along a fixed route from the central plant and arrive at a refueling station, and then come back along the same truck route. For simplicity, the truck routes, which are determined using a GIS-based optimization algorithm, are treated as a line source of vehicle exhaust. The number of truck trips is estimated based on the assumed station size and the truck capacity (see Table 2).

To assess energy consumption and emissions of each pathway step, emissions factors and hydrogen infrastructure engineering/economic design models are used. A full fuel cycle energy use and emissions model, GREET1.7, which is developed and maintained at Argonne National Laboratory, is the source of emission factors [3,4]. We assume energy supply and vehicle characteristics that correspond to the current technologies (year 2005) represented in GREET1.7.

\subsection{Spatial layout of emission sources associated with hydrogen supply pathways}

The spatial locations of emission sources associated with various hydrogen pathway supply steps have a strong influence on the regional air pollution concentrations. In this study, 


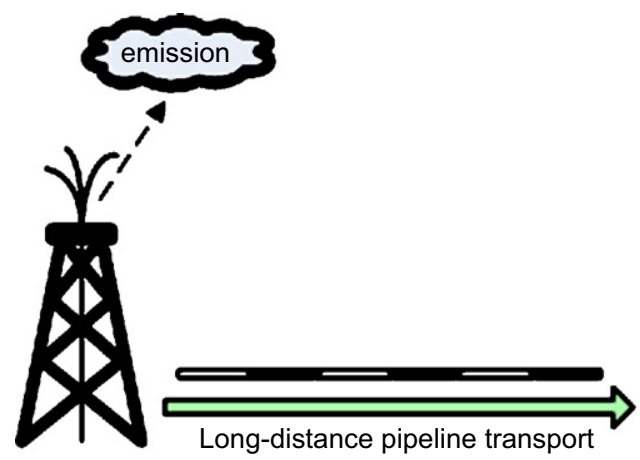

NG extration $\&$ cleanup

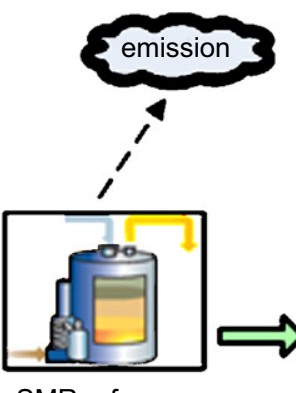

SMR reformer
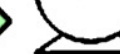

Compression
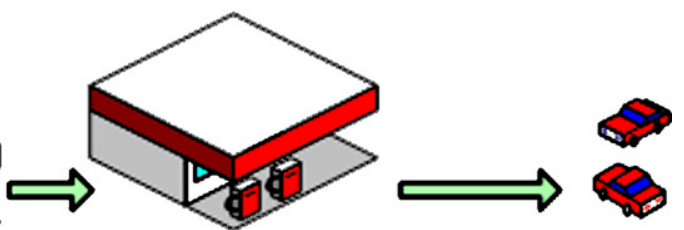

FCV operation

Onsite reforming facility

Fig. 1. NG to hydrogen pathway with onsite production.

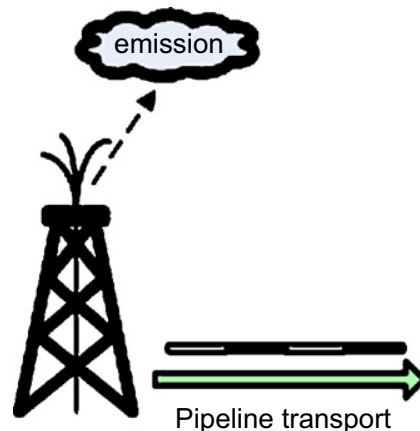

NG extrstion \& cleanup

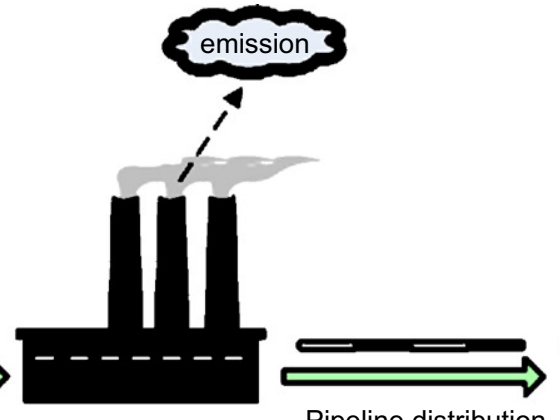

$\mathrm{H}_{2}$ production
Pipeline distribution

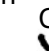

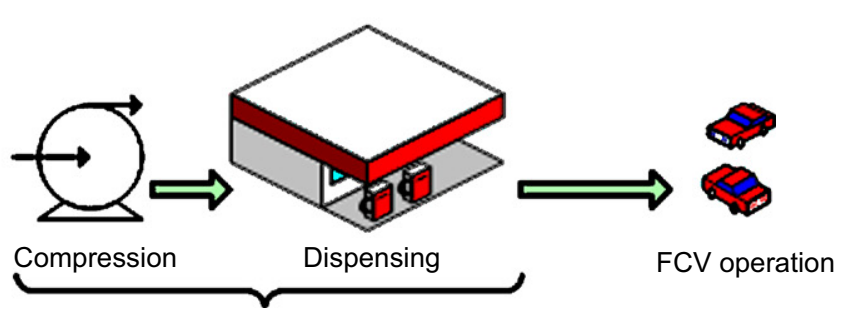

Refueling station

Fig. 2. NG to hydrogen pathway with pipeline delivery systems.

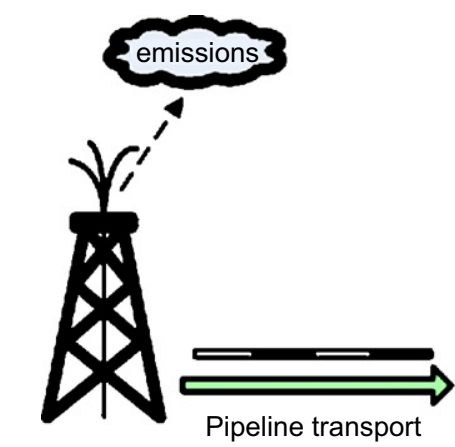

NG extraction \& cleanup

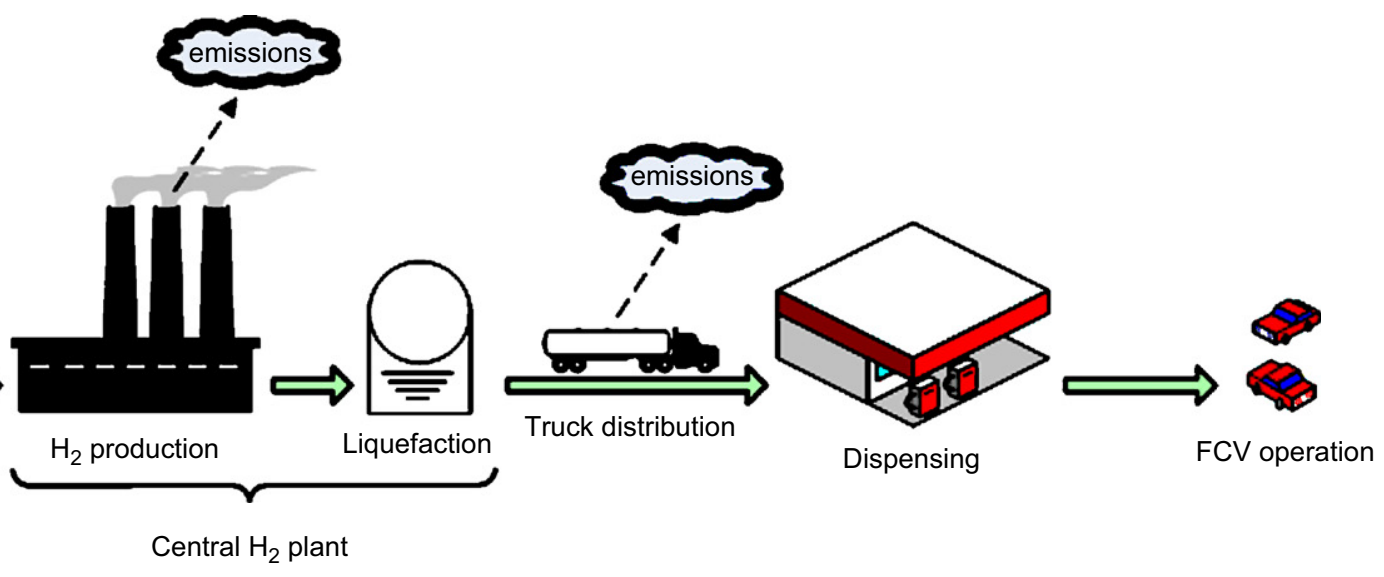

Fig. 3. NG to hydrogen pathway with liquid hydrogen truck delivery systems. we assume particular spatial locations for each step of the hydrogen supply pathway: natural gas extraction, hydrogen production, hydrogen delivery, and refueling stations. Each is described below. (We assume that hydrogen vehicles do not emit any air pollutants during operation, so the locations of hydrogen cars are not important for the analysis.)

Natural gas extraction and transport: Natural gas fields are located far from Sacramento, and therefore the impacts of natu- ral gas extraction and pipeline transport on air quality in urban Sacramento are neglected.

Centralized hydrogen production: A central hydrogen production plant is assumed to be close to currently existing natural gas-fired power plants in south Sacramento.

Refueling stations: We choose sites for hydrogen stations from among existing gasoline station locations in Sacramento. Hydrogen station sites are selected to minimize 
the average travel time from home to the closest station for all customers, given a certain number of stations. Customer locations are approximated using traffic analysis zones (TAZs). The method employs GIS data and optimization techniques and is described in detail by Nicholas [6]. The locations of stations in our study are shown

Table 3

Hydrogen supply technology efficiencies, on a lower heating value (LHV) basis

\begin{tabular}{llll}
\hline & $\begin{array}{l}\text { Onsite } \\
\text { pathway } \\
(\%)\end{array}$ & $\begin{array}{l}\text { Pipeline } \\
\text { pathway } \\
(\%)\end{array}$ & $\begin{array}{l}\text { Truck } \\
\text { pathway } \\
(\%)\end{array}$ \\
\hline Conversion efficiency & 69.0 & 71.5 & 71.5 \\
Compression efficiency & 94.0 & 92.5 & N.A. \\
Liquefaction efficiency & N.A. & N.A. & 70.5 \\
\hline
\end{tabular}

in Figs. 5 and 6. Fig. 5 corresponds to the scenario of a $9 \%$ market penetration and 27 refueling stations. Fig. 6 corresponds to the scenario of a $20 \%$ market penetration and 66 refueling stations.

Onsite hydrogen production at stations: Emissions associated with hydrogen production from small steam reformers at refueling stations occur at the station sites.

Hydrogen delivery: Liquid hydrogen trucks are assumed to travel on real-world highways and the actual route that each truck (from the central hydrogen plant to the station) travels is determined using GIS data on a minimum travel time basis.

Electricity for hydrogen compression and liquefaction: As noted above, we use actual locations of utility plants in the Sacramento area to estimate incremental emissions associated with hydrogen compression and liquefaction at the hydrogen plant, and with compression at refueling stations.

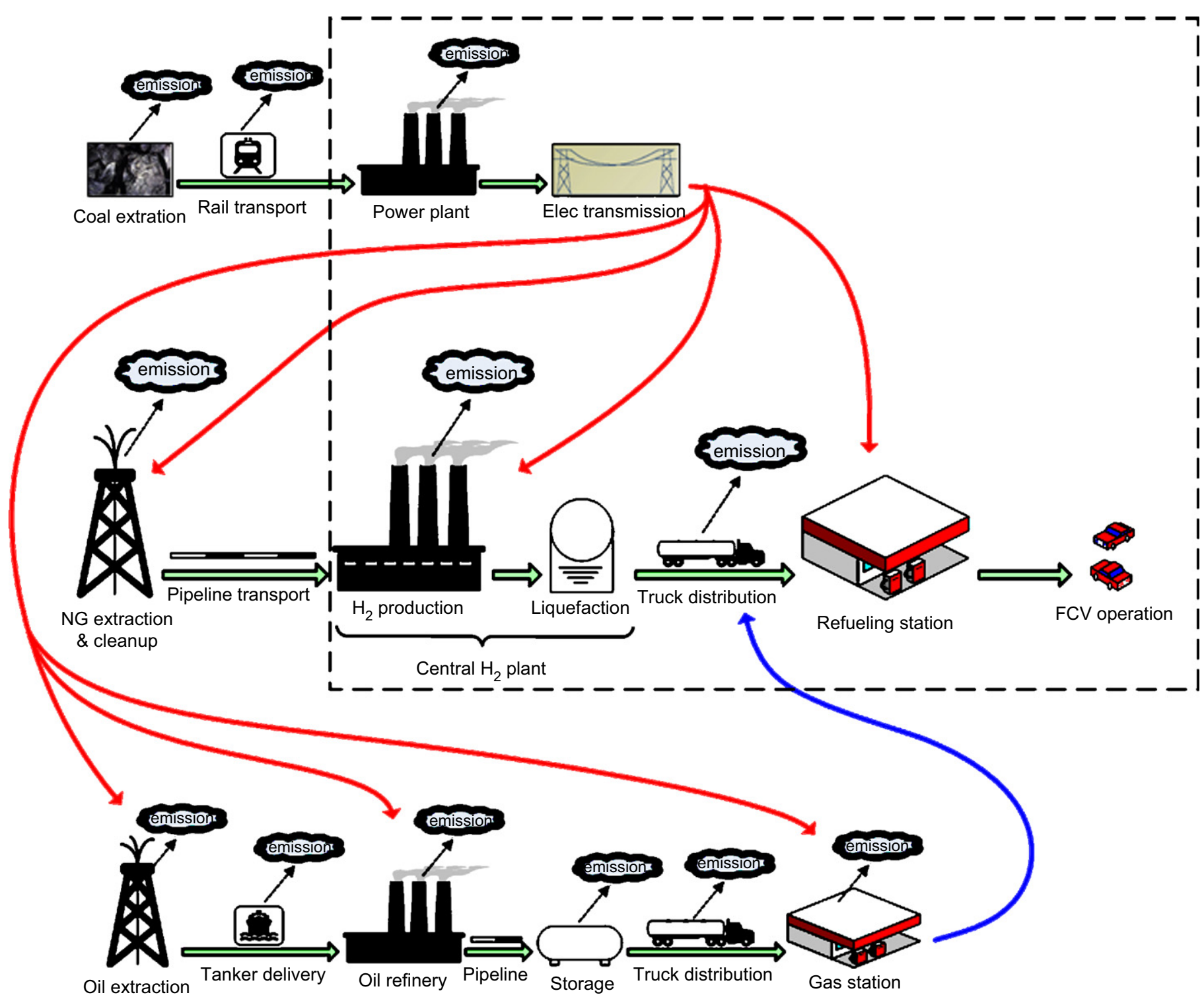

Fig. 4. Integrated NG-to- $\mathrm{H}_{2}$ pathway (liquid hydrogen example). 
Table 4

Sacramento PCA power plant profiles in 2000

\begin{tabular}{|c|c|c|c|c|}
\hline Plant name & County name & Primary & $\begin{array}{l}\text { fuel Generator } \\
\text { capacity } \\
\text { (MW) }\end{array}$ & $\begin{array}{l}\text { Annual net } \\
\text { generation } \\
(\mathrm{MWh})\end{array}$ \\
\hline Camino & El Dorado & Hydro & 154 & 429,969 \\
\hline Camp Far West & t Placer & Hydro & 7 & 31,560 \\
\hline Carson Ice CG & Sacramento & NG & 126 & 556,594 \\
\hline Hedge PV & Sacramento & Solar & 0.2 & 362 \\
\hline Jaybird & El Dorado & Hydro & 154 & 612,984 \\
\hline Jones Fork & El Dorado & Hydro & 12 & 22,297 \\
\hline Kiefer LF & Sacramento & Biomass & 9 & 74,731 \\
\hline Loon Lake & El Dorado & Hydro & 82 & 98,011 \\
\hline Mcclellan & Sacramento & NG, Oil & 74 & 15,743 (NG), 7 (Oil) \\
\hline PVUSA & Yolo & Solar & 1 & 253 \\
\hline Robbs Peak & El Dorado & Hydro & 30 & 49,464 \\
\hline SCA & Sacramento & NG & 150 & 649,213 \\
\hline Solano Wind & Solano & Wind & 7 & 6774 \\
\hline Solar & Sacramento & Solar & 2 & 1887 \\
\hline SPA & Sacramento & NG & 174 & $1,404,149$ \\
\hline Union Valley & El Dorado & Hydro & 47 & 139,504 \\
\hline White Rock & El Dorado & Hydro & 230 & 592,124 \\
\hline PCA total & & & 1257 & $4,685,626$ \\
\hline
\end{tabular}

Table 5

Sacramento PCA resource mix in 2000

\begin{tabular}{lc}
\hline Power-plant type & Generation mix $(\%)$ \\
\hline Oil & 0.0001 \\
Biomass & 1.59 \\
NG & 56.04 \\
Coal & 0.00 \\
Nuclear & 0.00 \\
Solar & 0.05 \\
Wind & 0.14 \\
Hydro & 42.17 \\
Total & 100.00 \\
\hline
\end{tabular}

\subsection{Atmospheric transport and urban air quality}

We employ a complicated model for atmospheric transport of pollutants to estimate increases in pollutant concentrations in the Sacramento area for each hydrogen supply case. We employ the spatial layouts in Figs. 5 and 6 for the 9\% and 20\% market penetration cases.

We estimate concentrations at nine "receptor sites" in Sacramento corresponding to actual locations of air pollution monitors. This allows us to compare the incremental changes in ambient concentrations due to hydrogen against actual measured ambient concentrations. Only increases in air pollution due to primary criteria pollutants and ozone precursors are estimated; i.e. the focus is on the following directly emitted pollutants: $\mathrm{CO}, \mathrm{VOC}, \mathrm{NO}_{x}, \mathrm{PM}_{10}$, and $\mathrm{SO}_{x}\left(\mathrm{NO}_{x}\right.$ refers to both $\mathrm{NO}$ and $\mathrm{NO}_{2}$ here, and $\mathrm{SO}_{x}$ refers roughly to $\mathrm{SO}_{2}$.). We assume that each emission source along the hydrogen pathways emits pollutants at a constant rate. We further assume that pollutants disperse on an urban or regional scale, and the distance from an emission source to any air quality

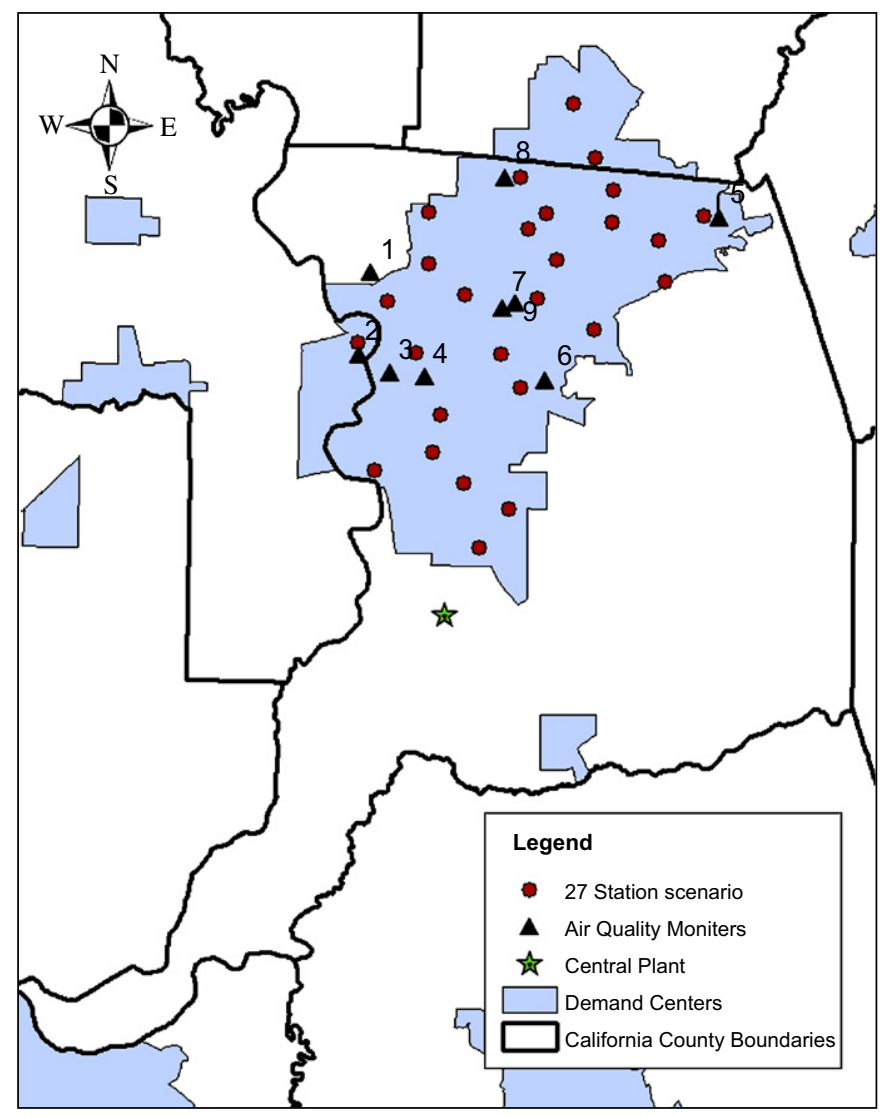

Fig. 5. Spatial layout of refueling stations, central plant, and receptors $(9 \%$ scenario).

monitor of concern is less than $100 \mathrm{~km}$, which assures that the above pollutants can be considered as conserved pollutants [7]. Studies by other researchers show that incremental annual concentrations are of much more interest than hourly or daily fluctuations since they are more feasible and simpler to use to estimate yearly external costs associated with human exposure to ambient pollution [7-9].

Only physical transport of the above pollutants is taken into account, without considering chemical transformation or decaying of pollutants in the atmosphere. The Industrial Source Complex short term model, ISCST3, developed by US EPA, is a steady-state Gaussian atmospheric dispersion model which can assess pollutant concentrations from a wide variety of sources associated with industrial complexes [10]. We use this model to estimate air quality at the receptor locations.

Below is the basic equation of predicting the time-average concentrations downwind of an elevated point source, accounting for superposition due to reflection from the ground $[7,11,12]$.

$$
\begin{aligned}
C\left(x, y, z ; H_{\mathrm{E}}\right)= & \frac{Q}{2 \pi u \sigma_{y} \sigma_{z}} \exp \left[-\frac{y^{2}}{2 \sigma_{y}^{2}}\right]\left\{\exp \left[-\frac{\left(z-H_{\mathrm{E}}\right)^{2}}{2 \sigma_{z}^{2}}\right]\right. \\
& \left.+\exp \left[-\frac{\left(z+H_{\mathrm{E}}\right)^{2}}{2 \sigma_{z}^{2}}\right]\right\},
\end{aligned}
$$




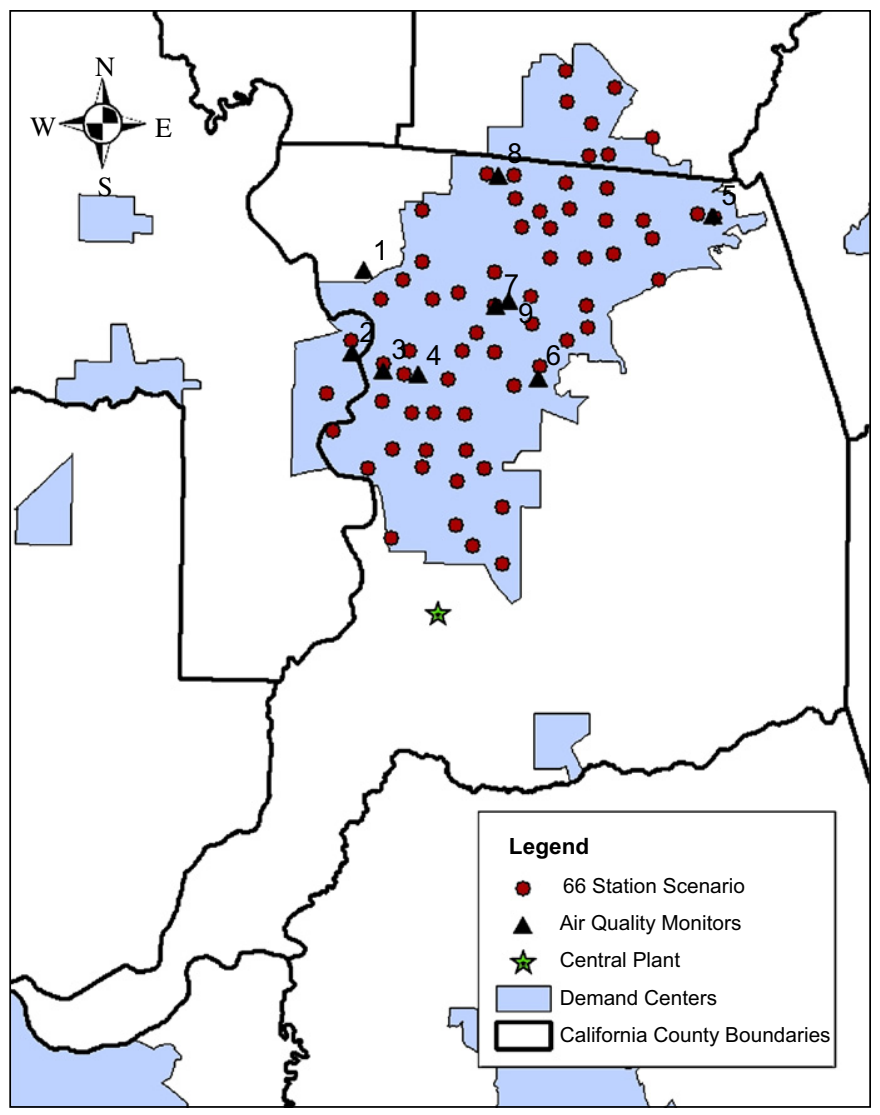

Fig. 6. Spatial layout of refueling stations, central plant, and receptors $(20 \%$ scenario).

where $H_{\mathrm{E}}$, effective stack height. $H_{\mathrm{E}}=$ physical stack height $(h)+$ plume rise $(\Delta H) ; C\left(x, y, z ; H_{\mathrm{E}}\right)$, concentration of the pollutant at a receptor location $(x, y, z) ; Q$, steady-state mass emission rate of the pollutant; $u$, mean wind speed at the effective stack height. $u=x / t$, where $t$ is the travel time of the pollutant from the release point to the location $(x, y, z)$; $\sigma_{y}$, transverse dispersion parameter. It is the standard deviation of the transverse concentration distribution at the downwind distance $x ; \sigma_{z}$, vertical dispersion parameter. It is the standard deviation of the vertical concentration distribution at the downwind distance $x$.

The Typical Meteorological Year 2 (TMY2), developed at National Renewable Energy Laboratory (NREL), is a complete annual cycle of hourly meteorological data extracted from the 30-year period of 1961-1990 to represent a typical longterm meteorological condition in a specific region [13]. To run ISCST3, such hourly meteorological data as hour of day, wind direction, wind speed, ambient temperature, atmospheric stability class, rural mixing height, and urban mixing height are needed. The TMY2 data set for Sacramento County is adopted in this research to predict changes in ambient air pollution under a historically representative meteorological condition rather than a worst-case condition $[12,14]$.

The Air Quality System (AQS) maintained by US EPA contains ambient air pollution data and profiles of thousands of air quality monitoring stations throughout the country; states,
Table 6

Air quality monitors in Sacramento (receptors of pollutants)

\begin{tabular}{ll}
\hline Monitor & Name and address \\
\hline 1 & Sacramento-3801 Airport Road \\
2 & West Sacramento-15th Street \\
3 & Sacramento-T Street \\
4 & Sacramento-Health Dept Stockton Blvd \\
5 & Folsom-Natoma Street \\
6 & Sacramento-Branch Center Road \\
7 & Sacramento-El Camino \\
8 & North Highlands-Blackfoot Way \\
9 & Sacramento-Del Paso Manor \\
\hline
\end{tabular}

local, and tribal agencies submit their data directly to AQS and EPA itself also collects data [15]. There are nine appropriate air monitoring stations officially maintained within or close to urban Sacramento based on the AQS system. These stations serve as receptors of pollutants in the research, and their profiles are shown in Table 6 [15]. Figs. 4 and 5 present their spatial layout in Sacramento. The individual incremental concentrations at these receptors and their average values represent the ambient pollution level attributable to each of hydrogen pathways. A receptor is not necessarily a typical representative of urban air quality when it happens to be located very close to a truck route or a refueling station.

Table 7 shows NAAQS primary standards, set by EPA in 1990 to protect public health $[16,17]$, and the actual pollution level in Sacramento in 2000, which is calculated based on the AQS data set above. It is important to keep these ambient "baseline" concentrations in mind, as we discuss the incremental concentrations due to additional large numbers of hydrogen vehicles.

\section{Results and discussion}

\subsection{Incremental pollution attributable to hydrogen pathways}

We use the ISCST3 program to estimate the additional pollution at a receptor for each of our three hypothetical hydrogen pathways. Figs. 7-16 present the magnitudes of incremental annual average concentrations of conserved pollutants due to existence of hydrogen pathways. There are three pathways (i.e., the onsite pathway, the pipeline pathway, and the truck pathway), five pollutants (i.e., $\mathrm{CO}, \mathrm{VOC}, \mathrm{NO}_{x}, \mathrm{PM}_{10}$, and $\mathrm{SO}_{x}$ ), and nine pollution receptors (denoted by $\mathrm{R} 1-\mathrm{R} 9$ ). It is easy to see that environmental impacts vary with receptor site, which reflect the location variations and geographic factors, even when they are attributable to the same hydrogen pathway.

The first thing to note is that all three hydrogen supply pathways result in very small incremental amounts of pollution compared to ambient pollution levels, on the order of $0.1 \%$ increase at $20 \%$ market penetration, and often much less. This is in contrast to recent results for natural gas based distributed generation of electricity in California, which resulted in more air pollution than central power plants [12]. 
Table 7

NAAQS and actual pollution level in Sacramento in 2000

\begin{tabular}{|c|c|c|c|}
\hline \multirow[t]{2}{*}{ Pollutant } & \multicolumn{2}{|l|}{ NAAQS (EPA,1990) } & \multirow[t]{2}{*}{ Sac. 2000 annual ave. conc. $\left(\mu \mathrm{g} / \mathrm{m}^{3}\right)$} \\
\hline & Primary standards & Averaging times & \\
\hline Carbon monoxide (CO) & $\begin{array}{l}9 \mathrm{ppm}\left(10 \mathrm{mg} / \mathrm{m}^{3}\right) \\
35 \mathrm{ppm}\left(40 \mathrm{mg} / \mathrm{m}^{3}\right)\end{array}$ & $\begin{array}{l}8 \mathrm{~h} \\
1 \mathrm{~h}\end{array}$ & 639.69 \\
\hline Volatile organic compounds (VOCs) & No standards & N.A. & $74.80(\mathrm{NMOC})$ \\
\hline Nitrogen dioxide $\left(\mathrm{NO}_{2}\right)$ & $0.053 \mathrm{ppm}\left(100 \mu \mathrm{g} / \mathrm{m}^{3}\right)$ & Annual (arith. mean) & 56.64 \\
\hline Particulate matter $\left(\mathrm{PM}_{10}\right)$ & $\begin{array}{l}50 \mu \mathrm{g} / \mathrm{m}^{3} \\
150 \mu \mathrm{g} / \mathrm{m}^{3}\end{array}$ & $\begin{array}{l}\text { Annual (arith. mean) } \\
24 \mathrm{~h}\end{array}$ & 22.45 \\
\hline Sulfur oxides $\left(\mathrm{SO}_{x}\right)$ & $\begin{array}{l}0.03 \mathrm{ppm}\left(80 \mu \mathrm{g} / \mathrm{m}^{3}\right) \\
0.14 \mathrm{ppm}\left(365 \mu \mathrm{g} / \mathrm{m}^{3}\right)\end{array}$ & $\begin{array}{l}\text { Annual (arith. mean) } \\
24 \mathrm{~h}\end{array}$ & 7.92 \\
\hline
\end{tabular}

${ }^{a}$ EPA revoked the annual $\mathrm{PM}_{10}$ standard in 2006 (effective December 17, 2006).

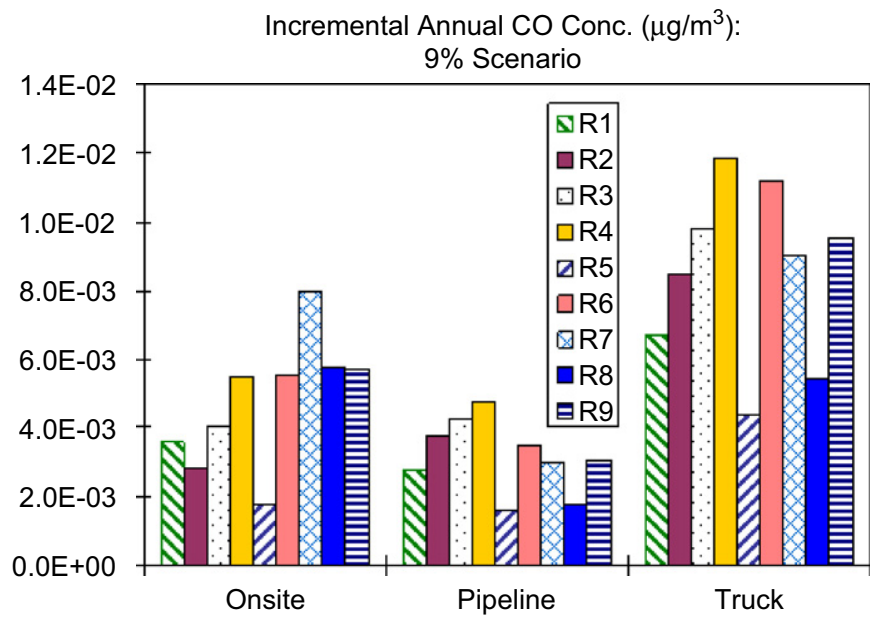

Fig. 7. Incremental annual average concentration of CO (9\% scenario).

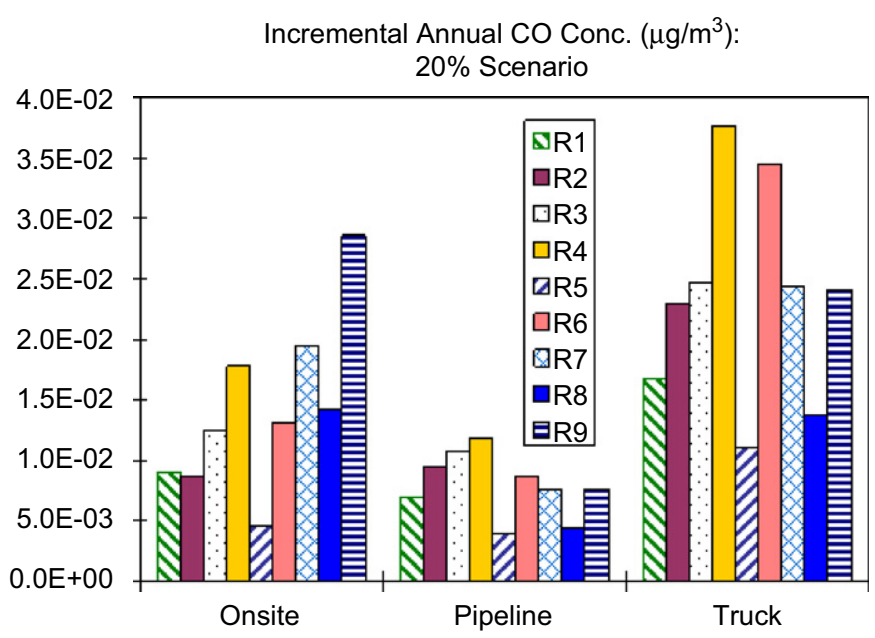

Fig. 8. Incremental annual average concentration of CO (20\% scenario).

For the truck pathway, emissions tend to be higher than for the other two supply pathways. As shown in Figs. 17-21 most of the emissions for the liquid truck pathway are due to diesel truck emissions resulting from the delivery of the liquid hy-

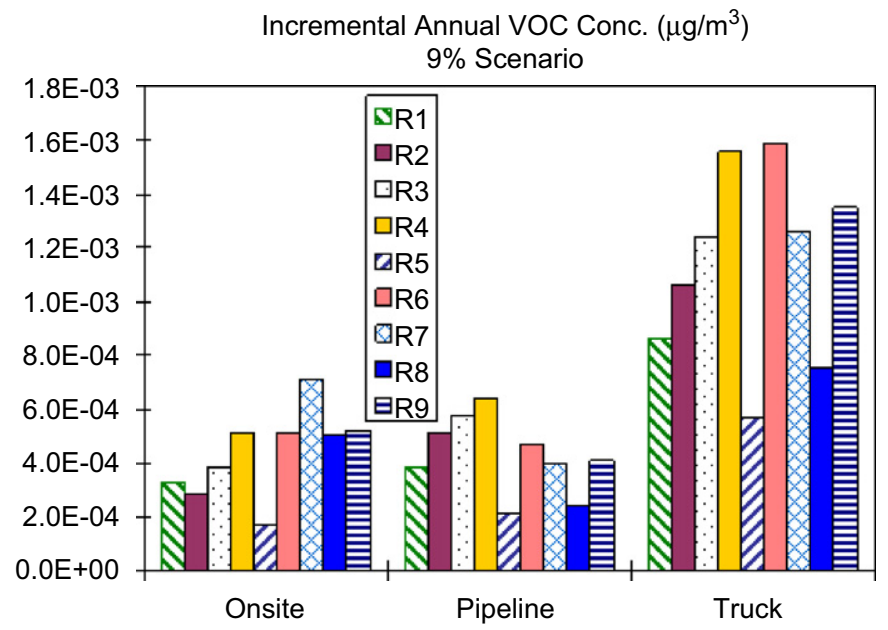

Fig. 9. Incremental annual average concentration of VOC (9\% scenario).

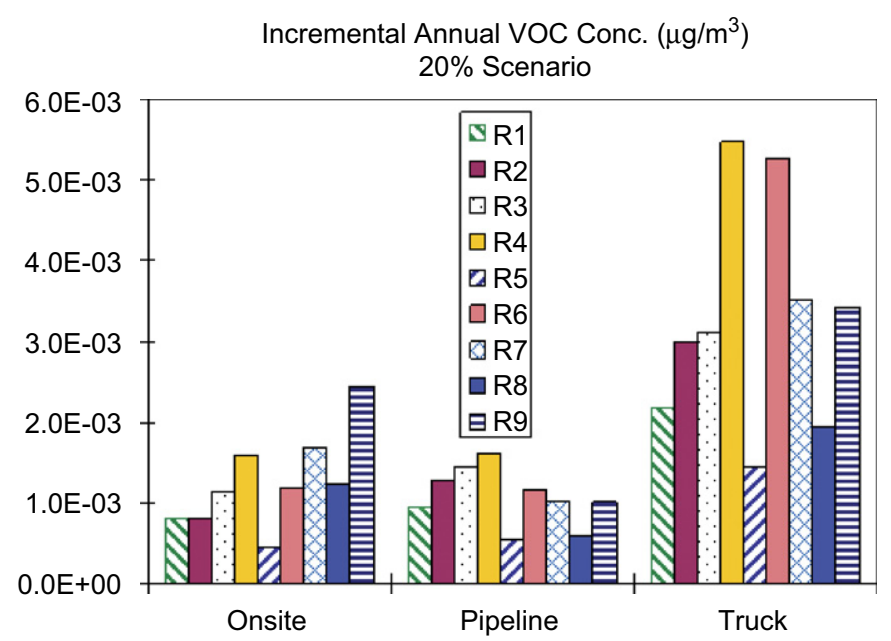

Fig. 10. Incremental annual average concentration of VOC (20\% scenario).

drogen and from the electricity used to liquefy the product hydrogen.

For the onsite scenario, there are no hydrogen delivery emissions since all the hydrogen fuel is produced and dispensed 


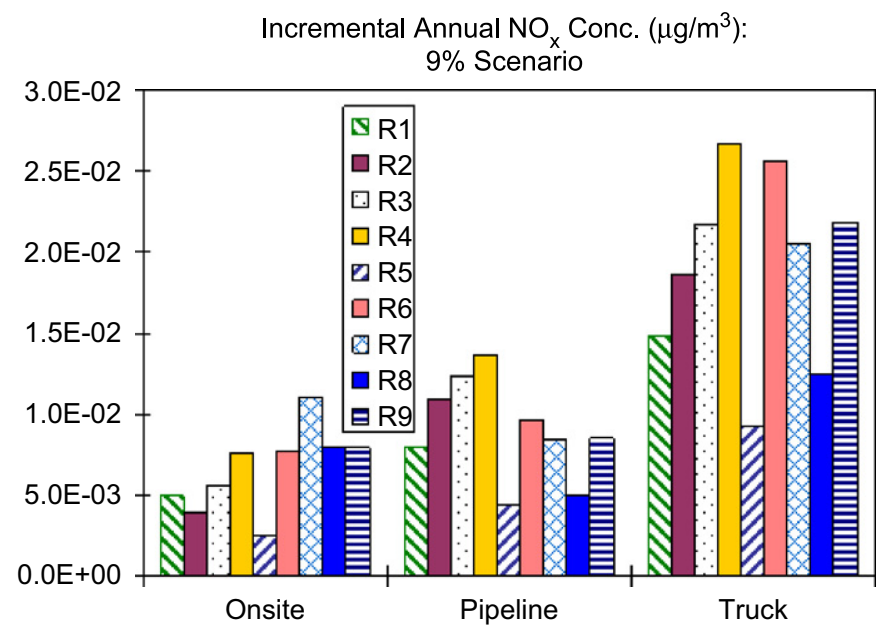

Fig. 11. Incremental annual average concentration of $\mathrm{NO}_{x}(9 \%$ scenario).

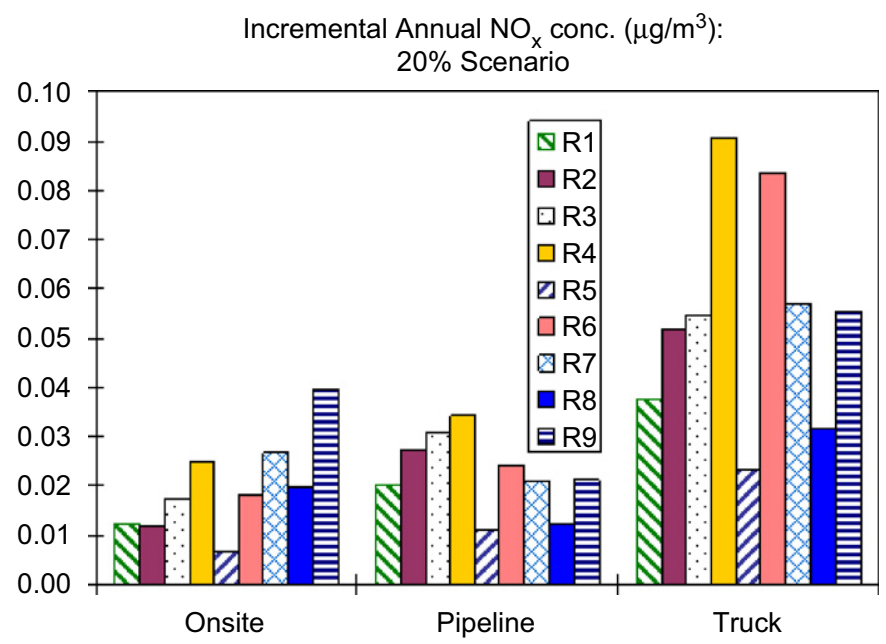

Fig. 12. Incremental annual average concentration of $\mathrm{NO}_{x}(20 \%$ scenario).

onsite at the refueling stations. Also, the emissions are distributed throughout the metropolitan area so the wind direction has little impact on the average air pollution at receptors.

It can be seen in the following charts that the change in air quality due to the onsite scenario is comparable to that caused by the central hydrogen pathway with pipeline systems, and both are very clean. The truck pathway also results in relatively low pollution levels, but higher than concentrations resulting from the other two pathways.

Meteorological conditions, especially wind directions, have a large impact on the effect of emissions from the central plant. The prevailing wind is from southwest to northeast, and wind is seldom from east to west in Sacramento. The site of the central plant can be strategically located so as to minimize the effect on urban air quality. In our example, the site is somewhat advantageous in that it is only occasionally upwind of the urban area. The site for the central plant could be further improved by placing it east of the metropolitan area since this location is almost always downwind of the urban region. Furthermore, it

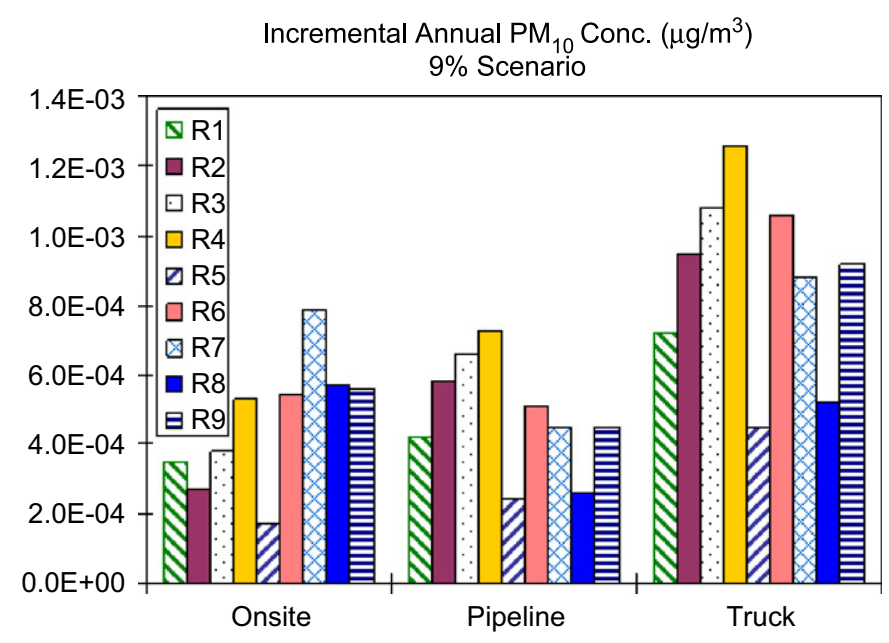

Fig. 13. Incremental annual average concentration of $\mathrm{PM}_{10}(9 \%$ scenario).

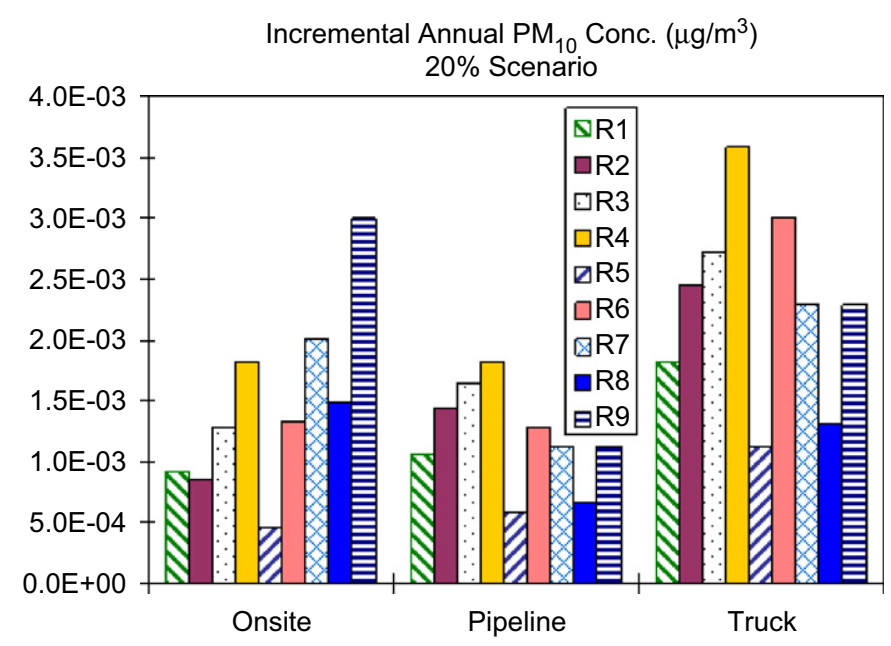

Fig. 14. Incremental annual average concentration of $\mathrm{PM}_{10}(20 \%$ scenario).

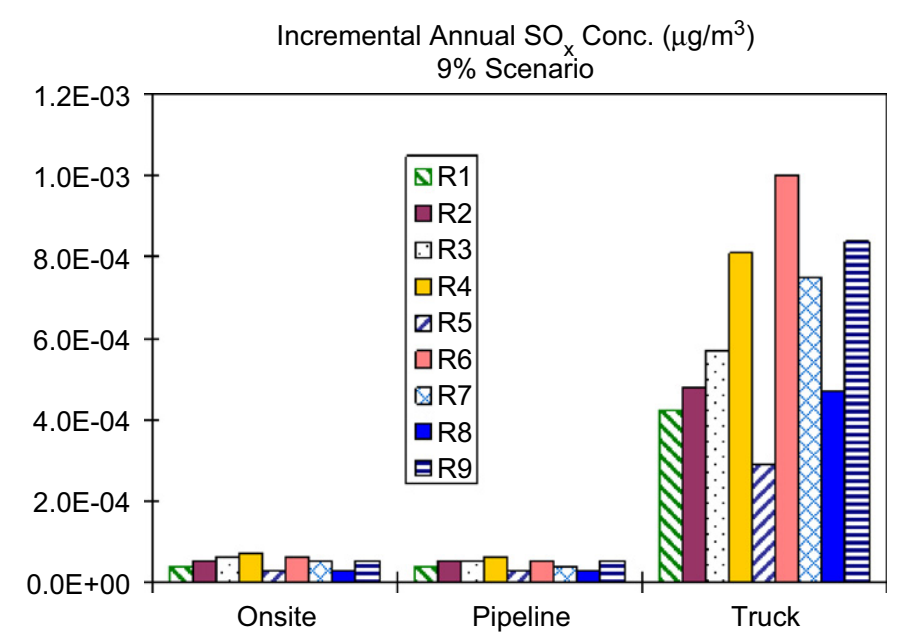

Fig. 15. Incremental annual average concentration of $\mathrm{SO}_{x}(9 \%$ scenario). 


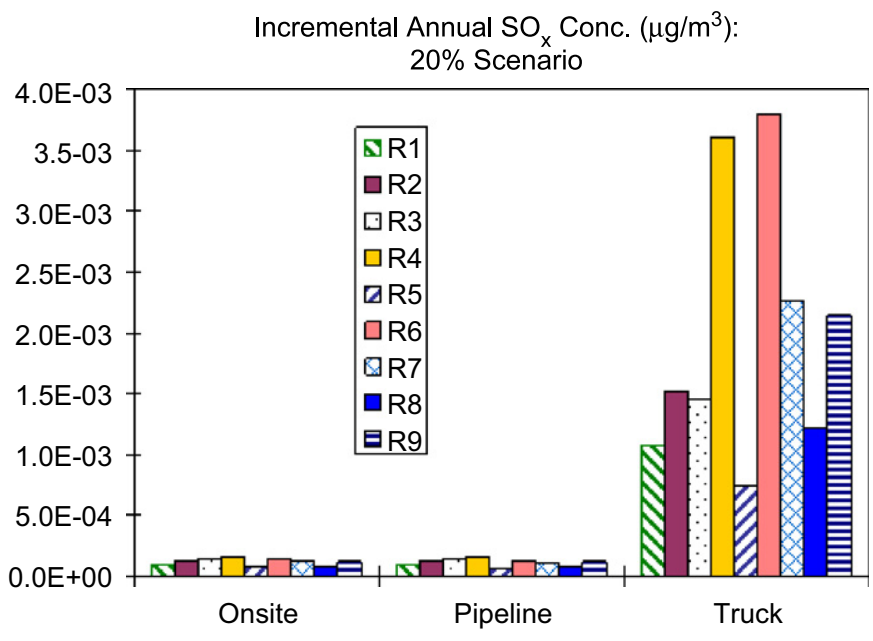

Fig. 16. Incremental annual average concentration of $\mathrm{SO}_{x}(20 \%$ scenario).

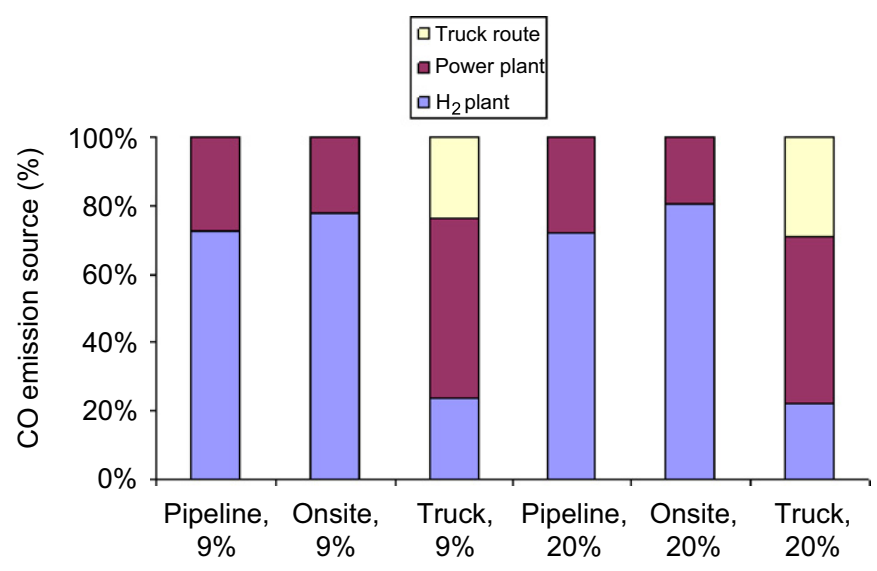

Fig. 17. Source pollution shares averaged over all receptors (CO).

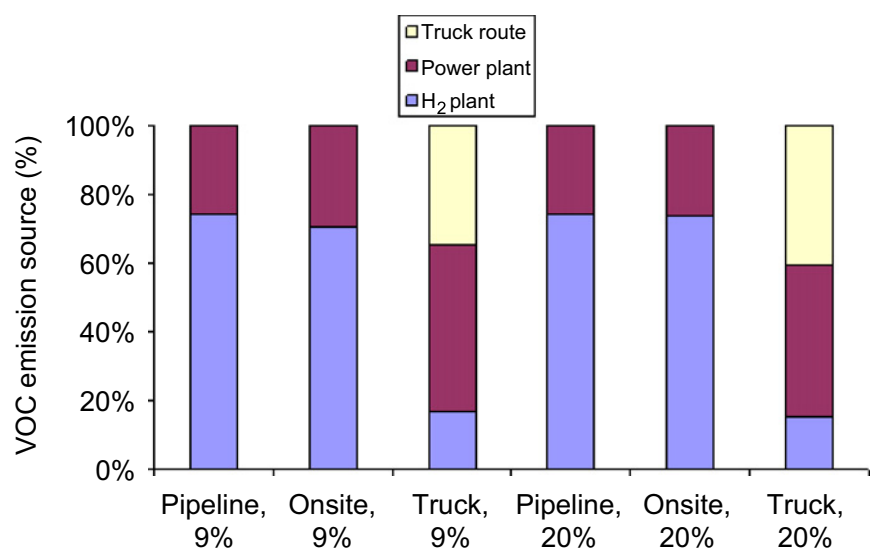

Fig. 18. Source pollution shares averaged over all receptors (VOC).

would be meaningful to carry out a sensitivity analysis regarding the central hydrogen plant siting, even though it is beyond the scope of this research. Again, geographic conditions have a significant effect on the impact of hydrogen production on urban air quality.

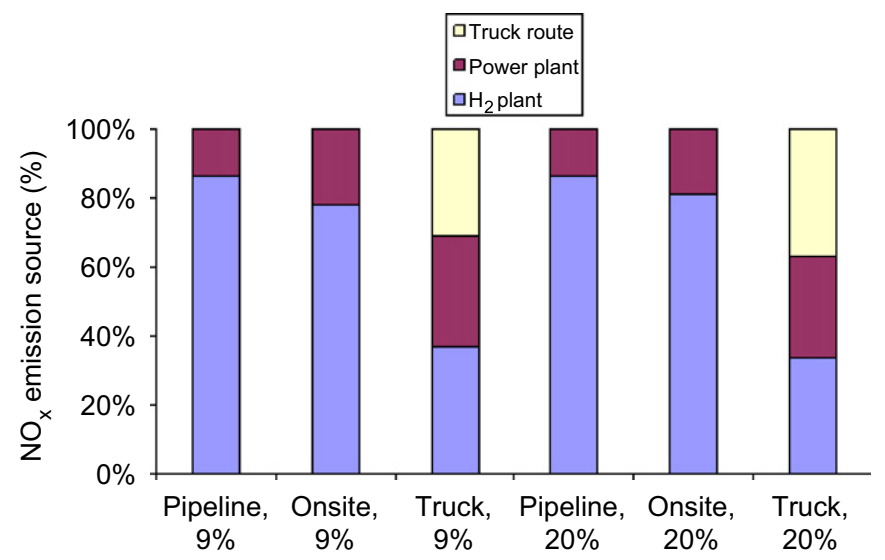

Fig. 19. Source pollution shares averaged over all receptors $\left(\mathrm{NO}_{x}\right)$.

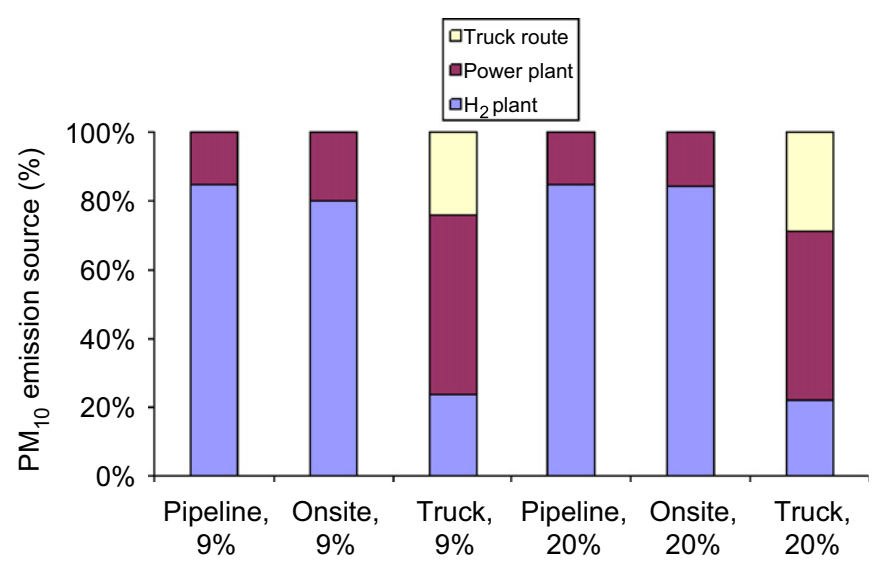

Fig. 20. Source pollution shares averaged over all receptors $\left(\mathrm{PM}_{10}\right)$.

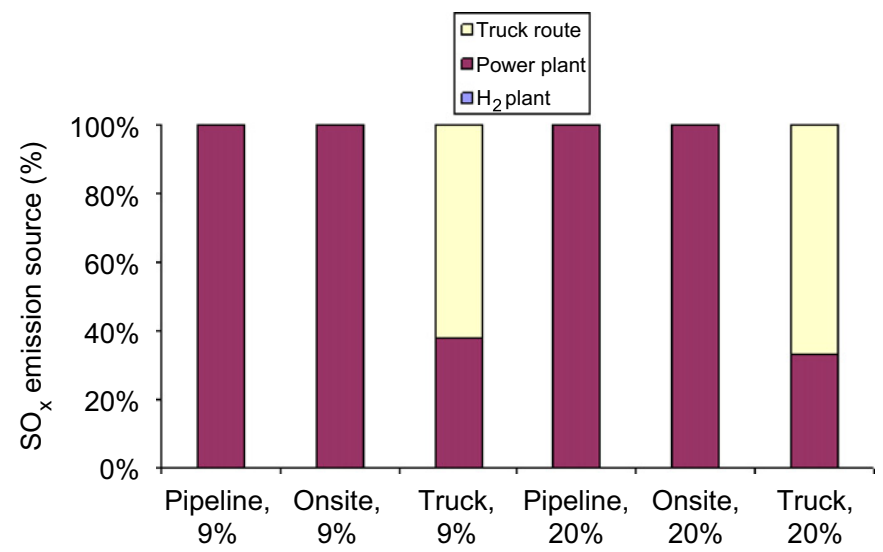

Fig. 21. Source pollution shares averaged over all receptors $\left(\mathrm{SO}_{x}\right)$.

\subsection{Comparison to the current ambient pollution level}

Table 8 compares the estimated incremental pollution from adding large numbers of hydrogen vehicles to the actual mean concentration of pollutants in Sacramento, averaging over all the nine receptors. For the 9\% scenario, the onsite pathway leads to incremental pollution fractions ranging from $0.0006 \%$ 
Table 8

Comparison of estimated incremental ambient pollution due to hydrogen pathways compared to ambient concentrations

\begin{tabular}{|c|c|c|c|c|c|c|c|}
\hline \multirow[t]{2}{*}{ Pollutant } & \multirow[t]{2}{*}{ Market penetration (\%) } & \multicolumn{2}{|l|}{ Onsite } & \multicolumn{2}{|l|}{ Pipeline } & \multicolumn{2}{|l|}{ Truck } \\
\hline & & $\begin{array}{l}\text { Mean conc. } \\
\left(\mu \mathrm{g} / \mathrm{m}^{3}\right)\end{array}$ & $\begin{array}{l}\text { Pollution } \\
\text { fraction }(\%)\end{array}$ & $\begin{array}{l}\text { Mean conc. } \\
\left(\mu \mathrm{g} / \mathrm{m}^{3}\right)\end{array}$ & $\begin{array}{l}\text { Pollution } \\
\text { fraction }(\%)\end{array}$ & $\begin{array}{l}\text { Mean conc. } \\
\left(\mu \mathrm{g} / \mathrm{m}^{3}\right)\end{array}$ & $\begin{array}{l}\text { Pollution } \\
\text { fraction }(\%)\end{array}$ \\
\hline \multirow[t]{2}{*}{$\mathrm{CO}$} & 9 & 0.00473 & 0.0007 & 0.00316 & 0.0005 & 0.00848 & 0.0013 \\
\hline & 20 & 0.01423 & 0.0022 & 0.00791 & 0.0012 & 0.02331 & 0.0036 \\
\hline \multirow[t]{2}{*}{ VOC } & 9 & 0.00043 & 0.0006 & 0.00043 & 0.0006 & 0.00114 & 0.0015 \\
\hline & 20 & 0.00126 & 0.0017 & 0.00107 & 0.0014 & 0.00326 & 0.0044 \\
\hline \multirow[t]{2}{*}{$\mathrm{NO}_{x}$} & 9 & 0.00654 & 0.0116 & 0.00896 & 0.0158 & 0.01909 & 0.0337 \\
\hline & 20 & 0.01967 & 0.0347 & 0.02241 & 0.0396 & 0.05394 & 0.0952 \\
\hline \multirow[t]{2}{*}{$\mathrm{PM}_{10}$} & 9 & 0.00046 & 0.0021 & 0.00048 & 0.0021 & 0.00087 & 0.0039 \\
\hline & 20 & 0.00146 & 0.0065 & 0.00119 & 0.0053 & 0.00229 & 0.0102 \\
\hline \multirow[t]{2}{*}{$\mathrm{SO}_{x}$} & 9 & 0.00005 & 0.0006 & 0.00004 & 0.0006 & 0.00063 & 0.0079 \\
\hline & 20 & 0.00012 & 0.0015 & 0.00011 & 0.0014 & 0.00198 & 0.0250 \\
\hline
\end{tabular}

( $\mathrm{SO}_{x}$, or $\mathrm{CO}$ approximation) to $0.0116 \%\left(\mathrm{NO}_{x}\right)$ of current ambient concentrations. The pipeline pathway leads to pollution fractions ranging from $0.0005 \%(\mathrm{CO})$ to $0.0158 \%\left(\mathrm{NO}_{x}\right)$, and the truck pathway leads to pollution fractions ranging from $0.0013 \%$ (CO) to $0.0337 \%\left(\mathrm{NO}_{x}\right)$. For the $20 \%$ scenario, the onsite pathway leads to pollution fractions ranging from $0.0015 \%$ ( $\mathrm{SO}_{x}$, or $\mathrm{CO}$ approximation) to $0.0347 \%\left(\mathrm{NO}_{x}\right)$, the pipeline pathway leads to pollution fractions ranging from $0.0012 \%(\mathrm{CO})$ to $0.0396 \%\left(\mathrm{NO}_{x}\right)$, and the truck pathway leads to pollution fractions ranging from $0.0036 \%$ (CO) to $0.0952 \%$ $\left(\mathrm{NO}_{x}\right)$.

Relatively speaking, hydrogen pathways contribute the least fractions to ambient $\mathrm{CO}$ and the most fractions to ambient $\mathrm{NO}_{x}$. It makes sense because most $\mathrm{CO}$ is released from urban mobile sources whereas $\mathrm{NO}_{x}$ is more likely from stationary sources resulting from combustion to produce high temperature steam which is used in the central hydrogen plant or in a power plant.

In summary, for all scenarios, the incremental pollution due to adding hydrogen cars at $9 \%$ or $20 \%$ market penetration is negligible. Truck pathways contribute more than onsite or central/pipeline pathways, but all have extremely low air pollution.

\subsection{Further comparison among hydrogen pathways}

Table 8 also shows a comparison of pathways in terms of resulting regionwide mean pollution. The truck pathway results in more pollution especially for $\mathrm{SO}_{x}$, with concentrations more than an order of magnitude higher than those from the other pathways. Liquid hydrogen trucks fueled with sulfur-containing diesel make the biggest contribution to ambient $\mathrm{SO}_{x}$ concentrations. This is due to several factors: the trucks run on US conventional diesel with an estimated sulfur mixing ratio of $200 \mathrm{ppm}$ by mass [3], steam reforming of natural gas is very clean in terms of sulfur-containing emissions, and electricity generation is relatively clean and renewables account for a very large share of production in Sacramento (see Table 5). The onsite pathway and the pipeline pathway result in very similar pollution levels, especially in terms of $\mathrm{VOC}, \mathrm{PM}_{10}$, and $\mathrm{SO}_{x}$.
However, the onsite pathway leads to more $\mathrm{CO}$ and less $\mathrm{NO}_{x}$ pollution than the pipeline pathway.

The incremental pollution due to each of hydrogen pathways, with the exception of the pipeline pathway, is not directly proportional to the regional hydrogen demand, denoted indirectly by HFCV market penetrations in the research (see Table 8). When the added hydrogen vehicle population increases by 2.5 times (from $10 \%$ up to $25 \%$ of the year 2000 light duty fleet), the pollution ratio increases by slightly more than 2.5 times, with the exception of $\mathrm{SO}_{x}$ pollution in the onsite pathway, which is slightly lower than 2.5 times. For the pipeline pathway, it is 2.5 times greater because it is assumed that the NG to hydrogen conversion efficiency remains the same as hydrogen demand goes up, holding the electric generation mix constant.

\subsection{Source contributions to incremental ambient pollution}

Based on the locations of emissions, the sources of ambient pollution are categorized into the following groups (ignoring the other emission sources that are spatially far away from urban Sacramento).

Hydrogen plant: This group includes the central hydrogen plant or onsite hydrogen production stations. Only emissions directly released from these locations are taken into consideration, and electricity consumed in a hydrogen plant is traced back to power plants that are referred to as another source contributor to ambient pollution.

Power plant: This group includes all the 17 power plants that contribute to the electric generation mix in Sacramento; in fact, only five power plants contribute to the urban air quality since the other 12 power plants, accounting for $42.36 \%$ of power mix, are on a clean energy basis (i.e., solar, wind, and hydro). For simplicity, only emissions directly released in power plants are taken into consideration, i.e. ignoring emissions upstream of power plants.

Truck route: This group only applies to the hydrogen pathway with liquid hydrogen truck delivery systems. The direct emissions are mainly diesel truck tailpipe emissions.

The source contributions to ambient pollution averaged over nine urban receptors of interest are presented in Figs. 17-21. 
For the pipeline pathway, the hydrogen plant accounts for the largest share of pollution, and its contributions (among all the air quality monitors) are typically larger than $70 \%$, and sometimes even larger than $80 \%$. The exception is $\mathrm{SO}_{x}$ pollution, which is almost $100 \%$ from power plants.

For the onsite pathway, the hydrogen production stations account for the largest share, typically more than 70\%. And again, $\mathrm{SO}_{x}$ pollution is the exception as power plants account for almost all of the $\mathrm{SO}_{x}$ pollution. Some receptors are affected by onsite stations much more severely, especially receptors that are close to and downwind from one or more stations. On average, hydrogen stations contribute around $90 \%$ of incremental pollution at receptors.

For the truck pathway, there are mainly three pollution components: truck routes, the hydrogen plant, and power plants. For all the five pollutants, truck routes and power plants are very important. The hydrogen plant contributes the smallest share, around $10-30 \%$, and essentially $0 \%$ in terms of $\mathrm{SO}_{x}$. Truck routes contribute $20-40 \%$ of pollution at a receptor, and particularly lead up to $70 \%$ in terms of $\mathrm{SO}_{x}$ pollution. Power plants contribute around $30 \%$ of pollution at a receptor for $\mathrm{NO}_{x}$ and $\mathrm{SO}_{x}$, and they contribute around $50 \%$ pollution for the other three pollutants.

\section{Conclusions}

We have examined the potential regional air quality impacts of hydrogen transportation fuel from a LCA perspective, including impacts from fuel production, delivery, and vehicle use. The analysis focuses on in a specific region, Sacramento County, California. We consider two levels of market penetration where $9 \%$ or $20 \%$ of the light duty fleet are HFCVs. Three natural gas-based hydrogen supply pathways are considered: onsite production via small scale steam methane reformer, and large central SMR with liquid truck delivery or pipeline delivery.

The source contributions to incremental air pollution are estimated using a physical transport model for primary air pollutants $\mathrm{NO}_{x}, \mathrm{CO}$, particulates, and $\mathrm{SO}_{x}$. (We use a Gaussian plume dispersion model for the atmospheric transport of pollutants. However, it does not include chemical production of secondary pollutants such as $\mathrm{O}_{3}$ formed by VOCs and $\mathrm{NO}_{x}$ in the presence of sunlight. Therefore, this research is not a complete environmental impact assessment of potential hydrogen pathways.)

The pollution levels associated with each of the hydrogen scenarios are dependent upon the location of emitters and receptors, regional meteorological conditions, and geographic factors. The spatial layout of pathway steps therefore plays an important role in determining ambient pollution levels at air quality monitoring stations. We find that all of the hydrogen pathways considered are associated with extremely low pollution levels relative to current ambient air concentrations of $\mathrm{NO}_{x}$, $\mathrm{CO}$, particulates, and $\mathrm{SO}_{x}$. The results are typically less than $0.1 \%$ of the current ambient pollution.

Among the hydrogen supply options, it is found that the central SMR with pipeline delivery systems is the lowest pollution option available provided the plant is located to avoid transport of pollutants into the city via prevailing winds. The onsite hydrogen pathway is comparable to the central hydrogen pathway with pipeline systems in terms of the resulting air pollution. The pathway with liquid hydrogen trucks has a greater impact on air quality relative to the other pathways due to emissions associated with diesel trucks and electricity consumption to liquefy hydrogen. The truck pathway causes more pollution than the onsite pathway and the pipeline pathway. The truck pathway causes around 15 times more $\mathrm{SO}_{x}$, and around 3 times more of the other pollutants, compared to the other two pathways. For the pipeline pathway and the onsite pathway, hydrogen production accounts for the largest share of pollution. For the electricity-intensive liquid hydrogen truck pathway, emissions from diesel truck delivery and electric generation at power plants are much more important than hydrogen plant emissions in terms of resulting pollution. Again, compared to ambient concentrations, all of the three hydrogen pathways result in negligible air pollution in the region.

This study shows that emissions from near-term hydrogen production and delivery systems would make negligible contribution to ambient air pollution. In future work, we plan to compare the emissions from hydrogen systems to those from other advanced vehicle fuels, including advanced gasoline vehicles.

\section{Acknowledgments}

The authors would like to thank the Hydrogen Pathways program in the Institute of Transportation Studies (ITS) at the University of California, Davis for its support.

The authors appreciate the information provided by Dr. Christopher Yang (ITS, UC Davis) and Garvin A. Heath (University of California Energy Institute). For useful conversations, the authors also wish to acknowledge Dr. Mark Delucchi (ITS, UC Davis), Dr. Marc Melaina (ITS, UC Davis), Jonathan Hughes (ITS, UC Davis), Nils Johnson (ITS, UC Davis), and Nicholas Lutsey (ITS, UC Davis).

\section{References}

[1] US Census Bureau. Population, area and population density of US urbanized areas from 2000 US Census http://www.census.gov/ geo/www/ua/ua2k.txt $\rangle ; 2006$ [accessed 1.25.2006].

[2] Wang G, Delucchi M. A lifecycle emissions model (LEM): lifecycle emissions from transportation fuels, motor vehicles, transportation modes, electricity use, heating and cooking fuels, and materials, APPENDIX X: pathways diagrams. University of California at Davis, Institute of Transportation Studies, Publication no. UCD-ITS-RR-0317X; June 2005.

[3] GREET1.7. The Greenhouse Gases, Regulated Emissions, and Energy Use in Transportation (GREET) Model. Argonne National Laboratory 〈http://www.transportation.anl.gov/software/GREET/index.html〉; 2006 [accessed 5.25.2006].

[4] Wang M. GREET 1.5-Transportation fuel-cycle model, 1, methodology, development, use and results, Center for Transportation Research, Argonne National Laboratory, prepared for the United States Department of Energy Office of Transportation Technologies. Report no. ANL/ESD40; December 1999.

[5] eGRID. Emissions \& Generation Resource Integrated Database. US EPA 〈http://www.epa.gov/cleanenergy/egrid/index.htm); 2006 [accessed 2.20.2006]. 
[6] Nicholas M. Hydrogen station siting and refueling analysis using Geographic Information Systems: a case study of Sacramento County. Masters Thesis. University of California, Davis; 2004.

[7] ExternE. Externalities of Energy, Methodology 1998 Update. European Commission 〈http://www.externe.info/reportex/vol7.pdf); 2005 [accessed 6.10.2005].

[8] Delucchi M, McCubbin D. The contribution of motor vehicle and other sources to ambient air pollution. Report \#16 in the series: the annualized social cost of motor-vehicle use in the United States, based on 1990-1991 data. University of California at Davis, Institute of Transportation Studies, Publication no. UCD-ITS-RR-96-3 (16) rev. 1; October 2004.

[9] McCubbin D, Delucchi M. The social cost of the health effects of motor-vehicle air pollution. University of California at Davis, Institute of Transportation Studies, Publication no. UCD-ITS-RR-96-03(11); August 1996.

[10] ISCST3. Industrial Source Complex model (Short Term 3). US EPA 〈http://www.epa.gov/scram001/dispersion_alt.htm); 2006 [accessed 5.25.2006].
[11] Seinfeld J, Pandis S. Atmospheric chemistry and physics: from air pollution to climate change. New York: Wiley; 1998.

[12] Heath GA, Granvold PW, Hoats AS, Nazaroff WW. Quantifying the air pollution exposure consequences of distributed electricity generation. University of California Energy Institute; May 2005.

[13] TMY2. National Renewable Energy Laboratory (NREL) 〈http://rredc.nrel.gov/solar/pubs/tmy2/〉; 2006 [accessed 5.25.2006].

[14] Heath GA. University of California Energy Institute. Private communications; November 2005.

[15] AQS. Air Quality System. US EPA /http://www.epa.gov/ttn/airs/airsaqs/ detaildata/downloadaqsdata.htm $\rangle ; 2006$ [accessed 3.2.2006].

[16] NAAQS. National Ambient Air Quality Standards. US EPA 〈http://www.epa.gov/air/criteria.html〉; 2006 [accessed 5.31.2006].

[17] CARB. Ambient Air Quality Standards. California Air Resources Board 〈http://www.arb.ca.gov/aqs/aaqs2.pdf); 2006 [accessed 5.31.2006]. 